\title{
Bruno Taut and the First World War
}

\author{
By Deborah Ascher Barnstone
}

It is commonly held that the experience of the First World War altered the course of avant-garde art and architecture in the Weimar period. Yet there were different experiences of the war; and the avant-garde was not a monolithic group either before 1914 or afterwards. Few histories discuss specific connections between the events of 1914-1918 and the explosion of creative activity that began as early as 1917 then continued through the 1920s. Yet by all accounts the war was a formative experience with a strong effect on all who lived through it whether seen from the vantage point of trenches along the Western Front, the Prisoner of War camps in East Prussia, or the increasingly pressured cities and towns at home. This essay traces the war experience and postwar response of the important German architect, Bruno Taut, who called the war "an epidemic of mental disorder." Taut was a leading anti-war activist/agitator who experienced the war on the home front in Magdeburg and was a founding member of many postwar avantgarde groups. The 1914 Cologne pavilion, done with Paul Scheerbart, might prefigure what was to come. However, Taut's work took a radical turn during the war. From the uninspired pragmatism of Falkenberg (1913) he turned to the fantasy and speculation of Alpine Architecture (1919).

"The First World War was ended. Jugendstil, and copying of historic styles in building had been abandoned earlier. Still, many believed and treasured [the idea] that something new had to come after the collapse." The architect, Max Taut, brother of the more famous Bruno Taut, penned these words looking back on the period in 1918 and 1919 just as Germany sat at the edge of war and revolution. Not only did Taut describe the effect the war had had on many architects and artists but also the general feeling amongst their fellow countrymen. His brief account dates to the 1960s but also reflects the feelings held by many of his contemporaries from 1914 onwards regardless of the political, or artistic orientation. War must lead to disaster and collapse then to renewal otherwise the war was in vain. Bruno Taut articulated what he viewed to be the expectations for architecture: it should show the "particular consequences arising from the War."

It is commonly held that the experience of the First World War altered the course of avant-garde art and architecture in the Weimar period. Nevertheless

*Professor, Faculty of Design, Architecture and Building, University of Technology, Australia.

${ }^{1}$ Bruno Taut, "Kriegs-Ehrung," Kunstgewerbeblatt, 1915, 174. 
there were many different experiences of the war and therefore many different consequences; the avant-garde was not a monolithic group either before 1914 or afterwards. Few histories discuss specific connections between the events of 1914-1918 and the explosion of creative activity that began as early as 1917 then continued through the 1920s. Certainly the motivations driving the many artists and architects in the Novembergruppe, Arbeitsrat für Kunst, Gläserne Kette, and other radical groups were as diverse as the experiences these artists had during the war. Yet by all accounts the war was a formative experience with a strong effect on all who lived through it whether seen from the vantage point of trenches along the Western Front, the Prisoner of War camps in East Prussia, or the increasingly pressured cities and towns at home. Although Taut asserted that the "particular consequences arising from the War" should inform architectural expression, he conveniently sidestepped any explanation of what this means for himself or for his contemporaries.

\section{Figure 1. Am Falkenberg Development (1913-1916)}

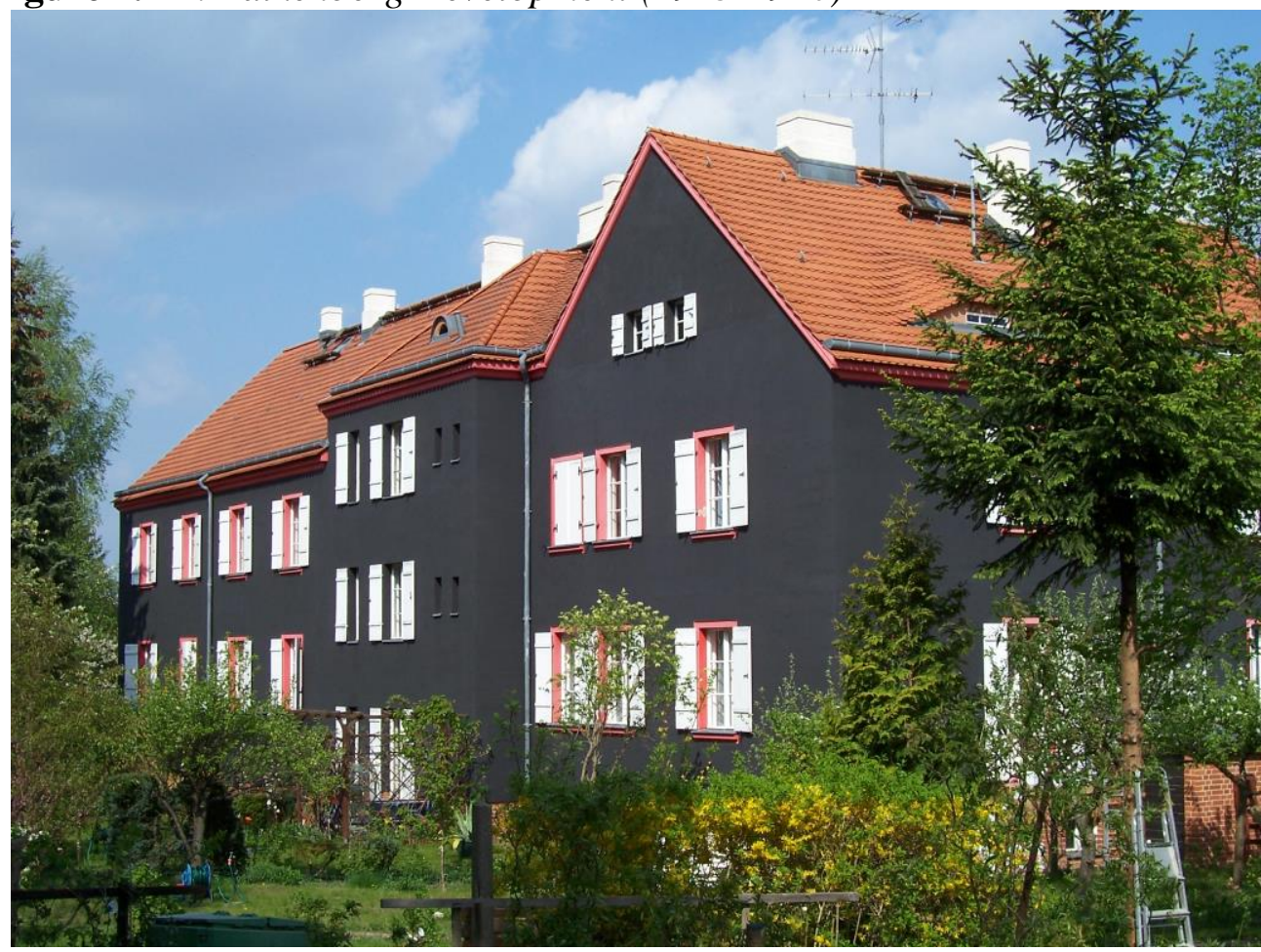

In Taut's case, the war experience seems to have given him license to intensify the more radical aspects of his work; the aesthetics temporarily become fantastic and utopian and the social project becomes extreme. From the uninspired architectural pragmatism of Falkenberg (1913), that was steeped in conventional social improvement aspirations, Taut turned to the fantasy and speculation of Alpine Architecture (1919), the City Crown (1919), Architecture for a New Community (1920), and the Dissolution of the Cities (1920). (Figure 1) Of special interest here is Alpine Architecture because Taut considered Alpine Architecture an anti-war manifesto; the communities and architecture he 
envisioned are not only ideal but also respond in very pragmatic ways to conditions caused by the First World War. Taut uses Alpine Architecture as an antidote to war. Build rather than destroy, is part of the tract's message, but also Alpine Architecture presents construction of utopian communities as the alternate channel for the human impulses and energy expended on war. At the same time, the project presents an alternative world to the reader, one where problems, like war and conflict, will be eradicated by the effort required to construct the spectacular architecture and by the sheer wonder that architecture and the natural landscape in which it is situated will instil in people.

Taut was certainly a pacifist. He railed against the war, calling it a "wicked ghost," "hopeless stultification," and "an epidemic of mental disorder." Unlike many other German youths who rushed to enlist during the heady August Days of 1914, Taut held back. Rather than a moment of progress that would usher in a new order, both social and artistic, Taut saw the war as folly and madness. ${ }^{2}$ It is true that on several occasions his correspondence from 1914-1916 includes the official patriotic line about the war. But these instances were rare and the partisan language formulaic and typical, which suggests that Taut may have felt compelled to use it. Or perhaps he was not initially certain how he felt about the war. By 1916, however, Taut was avowedly anti-war.

Born in 1880, he was 34 years old when the war broke out, so he should have enlisted. However somehow he managed to avoid both volunteering for the war effort and conscription. He seems to have successfully used a couple of strategies to stay out of the war. He moved around a great deal, which made him more difficult to track, and he had himself pronounced "indispensable" to the manufacturers who employed him; this gave Taut an argument against conscription. He claimed to be more useful to the war effort at home than he would have been on the front. In 1916, when he was most fearful of conscription, Taut mounted a hunger strike to make himself physically unfit to serve and thereby avoid being called up. ${ }^{3}$

At the outbreak of war, Taut travelled from Berlin to Kattowitz in Upper Silesia where the Hohenlohe Works employed him to design and construct two employee housing projects: the Städische Kolonie Oheimgrube and the Werksiedlung Oheim-grube. Both extend the work Taut had already done on housing before the war. They are simple blocks with small ornamental flourishes and efficient spatial planning. In October of 1915 he took a position in Brandenburg at a powder factory. Then he moved to Bergisch-Gladbach where he was declared indispensable to his employer, the Stella Works furnace factory. Thus, Taut passed the war years in different parts of Germany working for large industrial concerns. He was separated from his wife, Helga, during the period, living what sounds like a fairly lonely existence until he met Erica

\footnotetext{
${ }^{1}$ Bruno Taut, from the unpublished preface to Alpine Architecture ALP.01.42, Akademie der Künste, Berlin (hereinafter AdK).

${ }^{2}$ As Iain Boyd Whyte shows in his study, Taut seems to have been passionately anti-war from the start, in spite of a condolence letter he wrote to his sister-in-law Charlotte Wollgast in 1914 that was riddled with war clichés. Iain Boyd Whyte, Bruno Taut and the Architecture of Activism (Cambridge: CUP, 1982), 43-44.

${ }^{3}$ Iain Boyd Whyte,. Bruno Taut and the Architecture of Activism (Cambridge: CUP, 1982). 44.
} 
Wittich, who became his second wife. The work he was forced to do was unremarkable and uninspired. ${ }^{1}$ It was the polar opposite of what he would begin to create around 1917.

Although his early projects were not daring or unusual in their expression, Taut was interested, even obsessed, with discovering a new expression for architecture from the beginning of his career. ${ }^{2}$ It seems that Taut's personal search for new expression had three sides to it: pure aesthetics, the social, and the natural. All three interests have origins before the First World War when he started to work intensively on small houses and industrial buildings; he saw in these new programmatic types the answer to the $19^{\text {th }}$ century dilemma of styles and the correct area on which contemporary architects should focus. ${ }^{3}$ For a time, Taut was convinced that the principle goal for design had to be the combination of function, or program, and solution, and that by focusing on these two aspects of design, a new aesthetic for architecture would emerge that was the - "practical and aesthetic as a unity." During this period, Taut also became increasingly interested in architecture as an instrument for social good rather than merely an object with a socially conscious program. ${ }^{5}$ Taut gradually shifted his method of work, however, between 1915 and 1917. From using innovative architectural program to generate originality in his designs he turned to inventing new forms as the means of effectively implementing experimental architectural program.

Taut reveals the new direction his thinking is taking in a virtually unknown tract written and published in 1913 called, "A Necessity."6 In the article, Taut uses Kandinsky's paintings as an example of the direction in which architects must go. Kandinsky's work in 1912-1913 had moved into abstraction; the canvases are full of vibrant colour, animated lines and forms, and composed without recognizable objects or spatial relationships. Taut asserts that like Kandinsky and other contemporary artists, architects must achieve "freedom from perspective and single vantage points...the buildings of great architectural eras were invented without perspective...."7 Taut blames the over concern with perspective for trapping architects in a mode of thinking that produces flat, "backdrop" buildings rather than spatial experience. "Architecture," he writes, "should have rooms whose characteristic phenomena come from the new art...light compositions of Delaunay...Cubist rhythms...."

\footnotetext{
${ }^{1}$ Matthias. Schirren, Bruno Taut: Alpine Architektur. A Utopia; Bruno Taut: 1880-1938 Architekt zwischen Tradition $u$. Avantgarde ed. Winfried Nerdinger, Kristiana Hartmann, Matthias Schirren, Manfred Speidel (Munich: Deutsche Verlags-Anstalt. 2001).

${ }^{2}$ See Brigitte Renate Vera Lamberts, Das Fruhwerk von Bruno Taut (1900-1914), diss. University of Bonn, 1994, 107-117; and Barbara Volkmann, Bruno Taut 1880-1938. Ausstellung der Akademie der Künste vom 29. Jun ibis 3. August 1980. (Berlin: AdK, 1980). ${ }^{3}$ Bruno Taut, "Kleinhausbau und Landaufschliessung vom Standpunkt des Architekten," Gartenstadt: Mitteilungen der deutschen Gartenstadtgesellschaft, JG8, Heft 1, 9-12.

${ }^{4}$ Bruno Taut, "Die Neue Wohnung (Leipzig: Klinkhardt \& Biermann, 1924), 95.

${ }^{5}$ Barbara Volkmann, Bruno Taut 1880-1938. Ausstellung der Akademie der Künste vom 29. Juni bis 3. August 1980. (Berlin: AdK,1980).

${ }^{6}$ Bruno Taut, "Eine Notwendigkeit," Der Sturm, No. 196, 1913, 174-175.

${ }^{7}$ Ibid 174.
} 
rhythms...." In other words, he is searching for a way to develop new space and form. He recognizes that painting has made advances that suggest some paths forward for architecture. Taut is not yet really sure what this new architecture might look like or how to achieve it. He also calls for "religiosity" in design work, which seems to mean "passion" and "conviction." In spite of the fervour, Taut wishes to see behind design; he is realistic in his expectations. He understands art as "...the tensions between the ideas, the means, and the reality." 2 This view suggests a pragmatic notion of art as the result of the artist's struggle to mediate between the three parts of his work: the ideas and the constraints on those ideas and the means with which the ideas are realized. It therefore follows that as the ideas behind the architecture change the forms will change. In fact, this is precisely what occurred in Taut's work.

At this time Taut's thinking seems to swing radically away from social concerns to architecture as pure art "Every thought of social intentions should be avoided," he writes. The assertion is strange since, as Iain Boyd Whyte points out in Bruno Taut and the Architecture of Activism from a young age Taut was a committed reformist with a particular interest in social housing and the relationship between landscape and architecture. He was a member of the Choriner Kreis, a precursor to the nature groups of the 1920s, speculated on the relationship between architecture and nature from early on, and involved himself with the Deutsche Gartengesellschaft (German Garden Association), the organization that promoted garden city and similar green schemes. ${ }^{3}$ In fact, Taut's early large-scale developments like Am Falkenberg in Berlin and Reform in Magdeburg (1913) were garden city proposals with strong social agendas behind the designs. They were not, however, formally innovative.

Taut had an abiding admiration for Gothic architecture, which he saw as an example of the pinnacle of artistic collaboration and creativity along with communal involvement. ${ }^{4}$ After the war, Taut calls for the consolidation of the arts under the umbrella of architecture and uses the design and construction of the Gothic cathedral as the paradigm. But the Gothic is important for other reasons. It was a spiritual architecture; the cathedral space was exhilarating to enter; the interior was bathed in coloured light; and it was the primary communal social space in the Middle Ages. Taut read the medieval mystic Meister Eckhart enthusiastically and was also fascinated by the work of Gustav Theodor Fechner, philosopher/physicist. Taut likely was most attracted to Fechner's theory of pan-psychism, the belief that all of nature has a soul and is sentient. Taut argues that Gothic architecture, like all great buildings, evokes sensations of awe and wonder similar to those triggered in nature. ${ }^{5}$

As early as 1913, he published a tract lamenting the lack of direction in contemporary architecture and filled with ideas for how to develop a new

\footnotetext{
${ }^{1}$ Ibid, 175 .

${ }^{2}$ Bruno Taut, "Baugedanken der Gegenwart," Die Bauwelt, 1923, 341.

${ }^{3}$ Iain Boyd Whyte. Bruno Taut and the Architecture of Activism (Cambridge: CUP, 1982), 7-8. 8.

${ }^{4}$ Bruno Taut, “Eine Notwendigkeit,” Der Sturm, No. 196, 1913, 174-175.

${ }^{5}$ Bruno Taut, Natur und Baukunst, Stuttgart, 1904.
} 
style. ${ }^{1}$ In the piece, Taut postulates that the single biggest challenge for the architect is to embody the Zeitgeist in building. Taut uses the Gothic and Baroque as examples of two eras whose architecture he believes successfully reflected the ethos of the period.

Two projects from 1913 and 1914 are evidence of the aesthetic and formal struggles Taut was engaged with at the time: the 1913 Monument to Steel at the International Building Exposition in Leipzig and the 1914 Glass Pavilion at the Werkbund Exhibition in Cologne. (Figures $2 \& 3$ ) The historian Iain Boyd Whyte labels Taut's struggle as one between "the demands of function and simplicity on the one hand, and aesthetic delight and artistic fantasy on the other." "In both the Monument to Steel and the Glass Pavilion, Taut is clearly experimenting with form. The projects show Taut's interest in "light" and "Cubist form" yet they use them in fairly conventional ways within the parameters of contemporary German design by architects like Peter Behrens. ${ }^{3}$ The monument is a four-tiered octagon, which the famous architecture critic Adolf Behne considered "Cubist." Each tier is smaller than the one below so that the volume sets back as it rises off the ground. A gigantic gold sphere sits inside the uppermost openwork lattice tier quite like the dome atop the Cologne Glass Pavilion, only smaller and spherical. It recalls Joseph Maria Olbrich's Secession Building in Vienna as well as other historical domes. The tiers are ringed bands of floor-to-ceiling windows making the interior as filled with natural light as possible. Taut placed exposed steel columns on the outside and inside to advertise the pavilion's function, as a showcase for steel construction. At each level, inscriptions wrap around the building. The inscriptions list steel structures like bridges and factories and also list the names of professional steelworkers groups like the Steel Mill Association. In plan, the monument is symmetrical and centrally organized with an inner space surrounded by a ring of open space. The structure therefore anticipates the Cologne Pavilion in several formal moves.

\footnotetext{
${ }^{1}$ Bruno Taut, "Kleinhausbau und Landsaufschliessung vom Standpunkt des Architekten," Gartenstadt: Mitteilungen der Deutschen Gartenstadtgesellschaft, 8 Jg, Heft 1, 1914, 9-12. ${ }^{2}$ Iain Boyd Whyte. Bruno Taut and the Architecture of Activism (Cambridge: CUP, 1982), 29. ${ }^{3}$ Kai Gutschow, "From Object to Installation in Bruno Taut's Exhibit Pavilions," Journal of Architectural Education, 59, Iss. 4, May 2006, 63-71.
} 
Figure 2. Monument to Steel (1913)

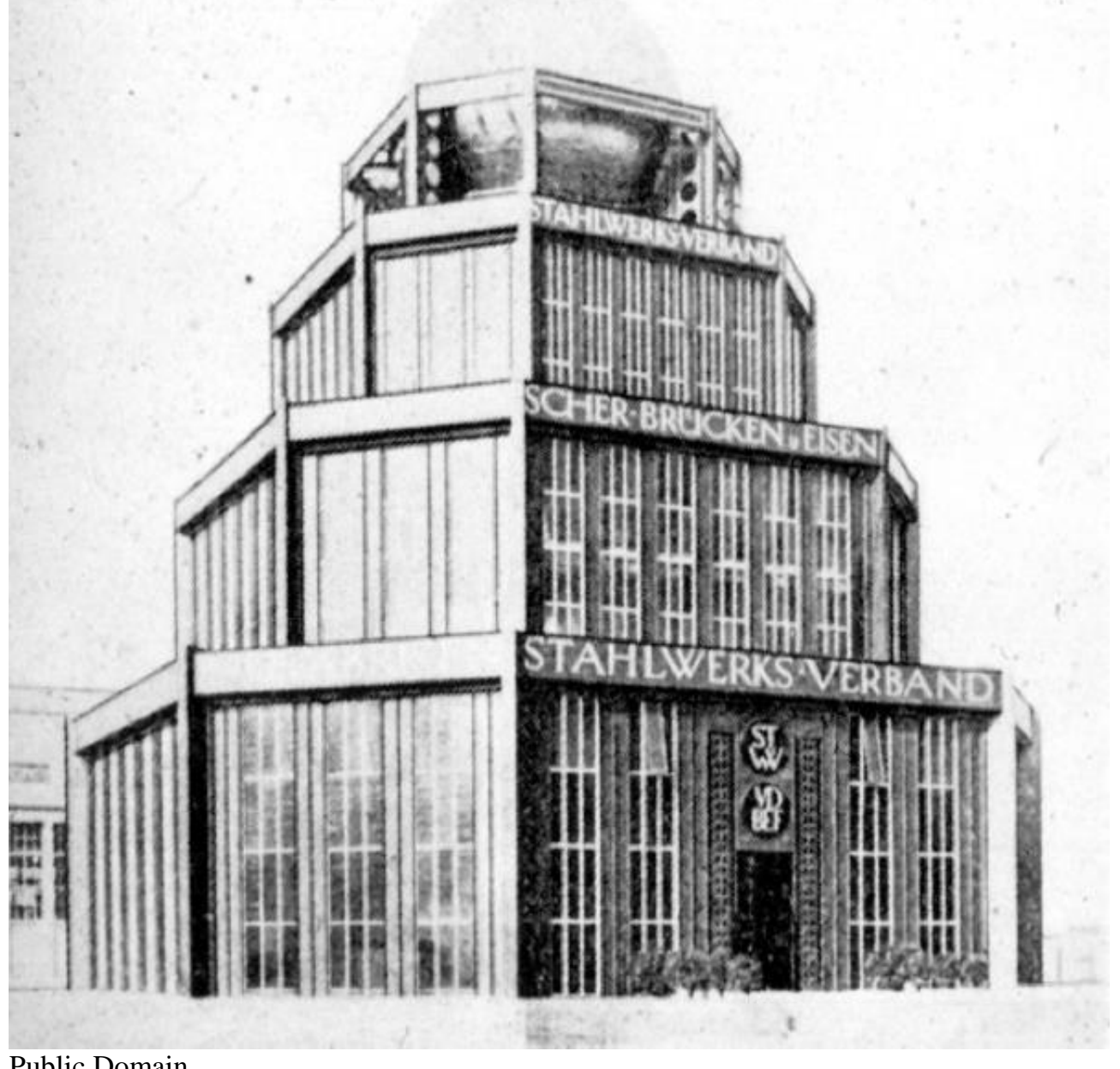

Public Domain

Adolf Behne acknowledges Taut's monument design for its appeal to the emotions, "innovative approach," use of primal forms and reliance on inner fantasy. ${ }^{1}$ In spite of Behne's opinion, the monument uses familiar forms albeit in a strange arrangement. It is in his recognition of the debt Taut owes to fantasy that Behne's appraisal is most useful; in its use of the octagonal plan, stacked and set back layers, and expressed steel, the monument departs from conventional form-making and shows that Taut is searching for a new formal language.

\footnotetext{
${ }^{1}$ Adolf Behne, "Das Monument des Eisens," Allgemeiner Beobachter 3, no. 12, October 1913, 167; Behne, "Das Monument des Eisens," Kunstgewerbeblatt, 25, no. 5, February 1914, 86-88.
} 
Figure 3. Glass Pavilion, Cologne Werkbund Exhibition (1914)

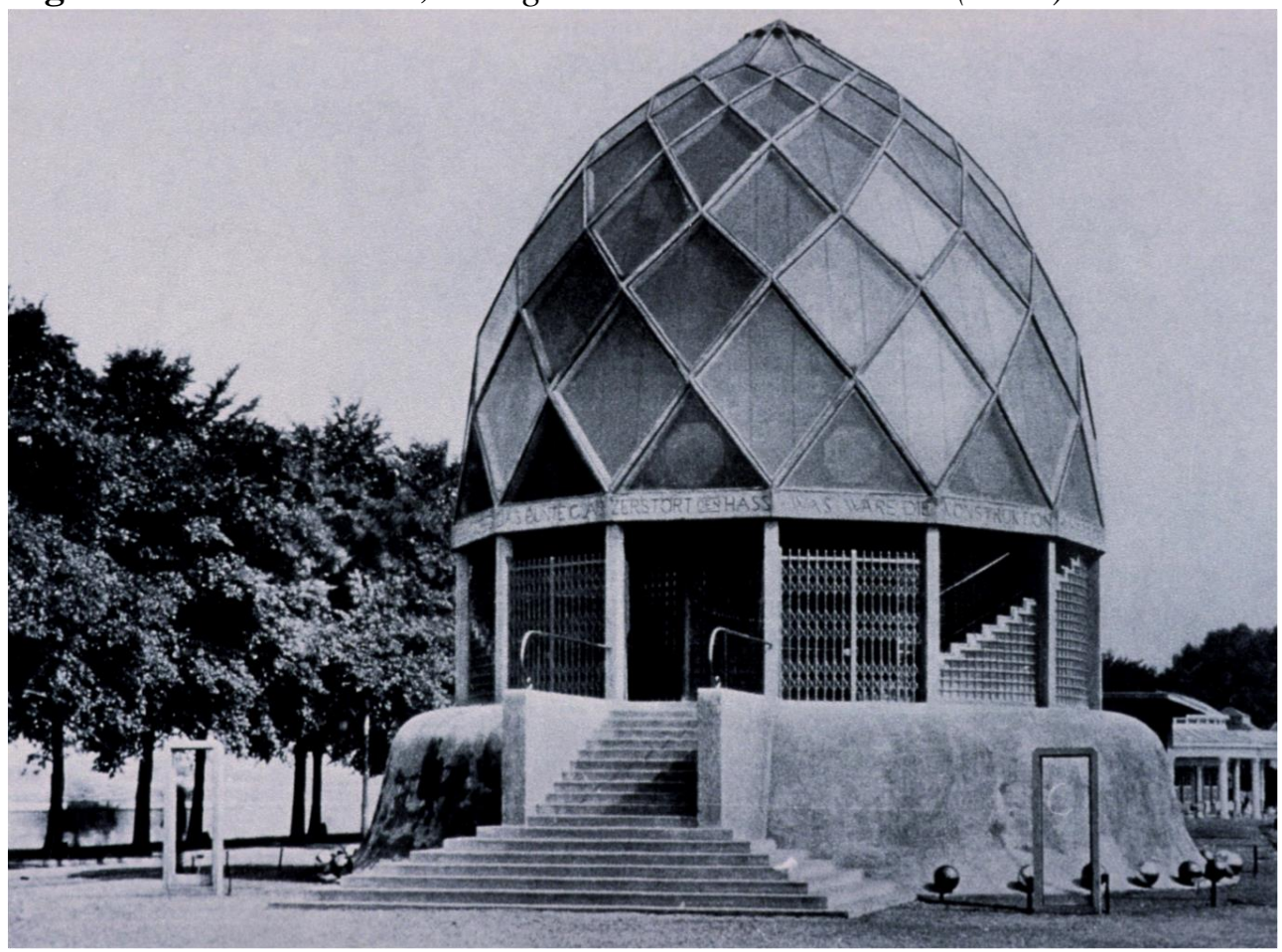

Public Domain

Taut's breakthrough project was the 1914 Glass House designed in collaboration with the German mystical writer and pacifist Paul Scheerbart. ${ }^{1}$ Taut had met Scheerbart through Gottfried Heinersdorff, who was the Artistic Head of the Glasmalerei-Werkstaetten, Puhl and Wagner, Berlin. ${ }^{2}$ Both men were involved in Der Sturm, one of the important prewar avant-garde movements in Germany. A central feature of Der Sturm was the search for new social and artistic forms as well as new purpose for both society and art.

Taut found Scheerbart's philosophy attractive on many levels and would be influenced by the older man throughout his career. The Glass Pavilion was a quasi-mystical construction that celebrated glass as an architectural material and, with its coloured glass pieces, harkened back to the stained glass of the Gothic cathedral. Whether Taut became a pacifist because of Scheerbart or was attracted to Scheerbart in part because of his strong pacifist views is not clear, but the two were both vehemently anti-war.

The ideas driving the design of the Glass Pavilion had utopian ambitions, as Paul Scheerbart's rhyming couplets demonstrate: "Coloured glass destroys hatred," "Glass brings us the new time: brick culture only makes us sorry." Although groundbreaking in many ways the pavilion is also awkward. Its use of coloured glass on as many surfaces as possible and its unusual formal resolution mark the pavilion as a unique project for the time that demonstrates,

\footnotetext{
${ }^{1}$ Paul Scheerbarts Briefe von 1913-1914 an Gottfried Heinersdorff, Bruno Taut und Herwarth Walden ed. Leo Ikelaar (Paderborn: Igel, 1996).

${ }^{2}$ Bruno Taut: 1880-1938 Architekt zwischen Tradition u. Avantgarde, 299.
} 
as Taut claimed, the as-yet unexplored possibilities inherent in glass construction. ${ }^{1}$ But when compared with the compositional freedoms of the fine art Taut admired, the pavilion seems timid. It is a perfect circle, symmetrical, static, and centrally focused. The oddly shaped dome sits uncomfortably on the reinforced concrete frame below, which has a similarly disjunctive relationship to the concrete base. While the form is unusual, it still remains stubbornly in the realm of a familiar form recalling cathedrals, Orthodox churches, and mosques. This is likely partly because of the real and obvious constraints associated with any architectural design project but also, perhaps, because Taut could not extricate himself from known forms.

Taut's short piece, "War Ceremony," from 1915, reveals a shift in his thinking during the war. In the essay, he makes a very persuasive argument against the design and construction of war monuments as a legitimate way for architects to occupy themselves during the war in favour of the design and construction of useful architecture that can serve returning soldiers and act as a "bridge between war and peace." While in some ways it sounds like an argument for just the social projects Taut eschewed in "A Necessity," it is actually a visionary document, not a pragmatic one. Taut is clearly looking ahead to anticipate the needs Germany will have in the postwar era without knowing for certain what they may be. Although he envisions practical things like housing with amenities situated in a large park, the vision is both practical and utopian at once. He writes, that a "new culture will arise" of people focused on the "Style of Living Forms." While Taut does not define "living forms" it is clear that he means new forms that respond to the altered circumstances in Germany after the war that must occur since war always alters the status quo. He asserts that through "new types of building, a people can lift itself to a higher cultural level." In the short piece, Taut lays out the basis for his immediate postwar program: architecture is the means with which to regenerate and elevate all culture and society. But it must be new architecture with new spatial and formal characteristics. On the title page of Frühlicht, Taut cites Karl Friedrich Schinkel, "Art is absolutely nothing if it isn't new." 2 Thus, Taut increasingly turns his imagination towards experimentation and freer forms of expression.

Taut does not seem to have been busy with design pursuits, utopian fantasies, or political concerns, during the first years of the war likely because his work demanded all of his time. It was not until 1917 to 1918 when he authored the book Alpine Architecture that Taut had his breakthrough. Alpine Architecture exploited Taut's drawing and painting talent in a way he had not tried before. Taut had discovered his gift for painting as early as 1904 when he wrote Max," I feel more and more like a painter." Taut even wondered whether he ought to abandon architecture for painting: "How deep is my talent? Because of my nature, I can probably live best in the world of painting -

\footnotetext{
${ }^{1}$ Bruno Taut, "Glasbau," n.d. Bruno Taut Archive, AdK, BTS 01-47.

${ }^{2}$ Frühlicht, Spring 1921, 1.
} 


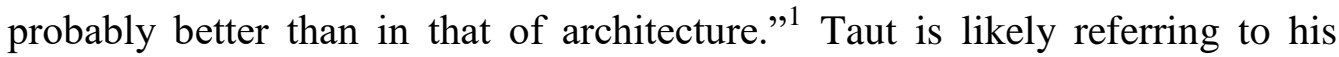
quasi-mystical and religious tendencies, which he could better express in the relatively unrestricted realm of art over the functionally, practically, and politically circumscribed profession of architecture. Taut only used his painterly abilities in mundane and conventional architectural applications until he drew Alpine Architecture in 1917, which combines a mystical text with stunningly colourful illustrations of a utopian world. (Figure 4)

Figure 4. The Construction Area on Monte Generoso, a Page from Alpine Architecture $^{2}$

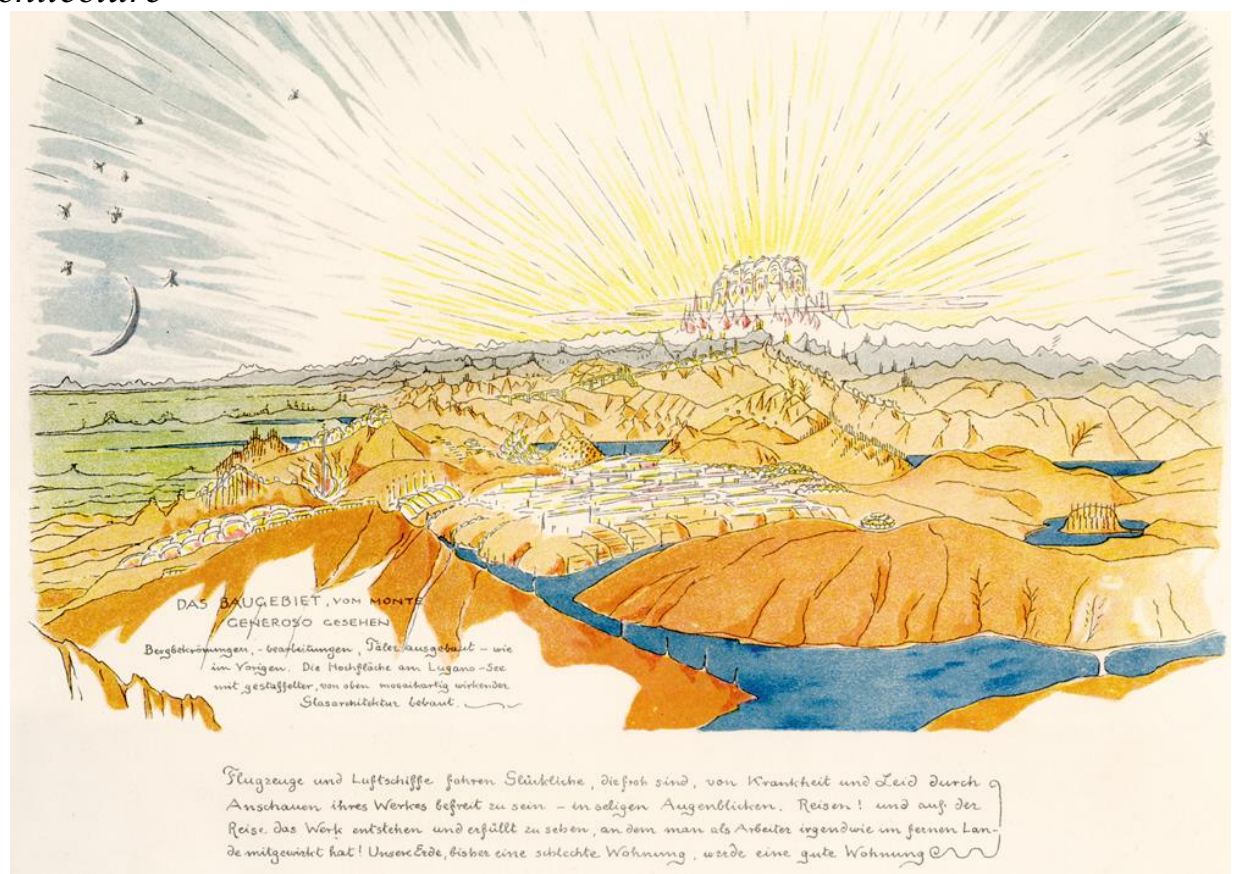

Photo: Akademie der Künste, Berlin

The preface to Alpine Architecture was not included in the published edition. It reveals Taut's intentions. In it, Taut begins by dedicating his work to Scheerbart. Taut writes, "the deepest reason for its [Alpine Architecture's] emergence lay in the heart of its creator - a heart that shed blood under all the pain of war in the world." ${ }^{\prime 3}$ And, in a letter to his brother Max, Bruno explains Alpine Architecture: "the nucleus is a pacifist idea, with which I want to fight

\footnotetext{
${ }^{1}$ BTA, AdK Berlin, Ausstellung 1980, 260 and cited in "Das Fruhwerk," in Bruno Taut 18801938 Architekt zwischen Tradition $u$. Avantgarde, 32.

${ }^{2}$ The caption reads: Crowning, reworking of peaks, development of valleys - as previously. The high plateau on Lake Lugano with glass architecture in series of rows, mosaic-like in effect when seen from below. Aeroplanes and airships bring happy people who are grateful to [be freed] of illness and suffereing by viewing their work. In blissful moments. Travelling! And on the journey witnessing the emergence and fulfilment of the work to which one has somehow contributed as a labourer in distant lands. Our Earth previously a poor dwelling, shall become a good dwelling.
}

${ }^{3}$ ALP, AdK, 01-42; trans. Matthias Schirren, 118. 
against the war."1 Although he was never at the front and never saw real military action, Taut claims to have felt the trauma of war as physical pain; "the heart that shed blood" is one reference. Even more dramatically, Taut writes, "Like Winkelried, it [Taut's body] received all of the bristling lances and pressed them into itself." Winkelried was a mythical figure in Swiss legend that supposedly sacrificed his life, to multiple lance wounds at the hands of the Habsburg knights, in order to win Switzerland its independence. Taut claims to have been pierced in a similar way to Winkelried, if only metaphorically; he felt deeply disturbed by the war in a visceral manner that was far more powerful than mere sympathy or empathy for the soldiers who were serving at the fronts. Taut can justify his refusal to physically participate in battles by claiming to have been there in spirit, because of his empathetic embodiment of the battlefield experience.

Taut goes on to explain the project Alpine Architecture as a "pure idea" meant to appeal to human imagination and wonder. He acknowledges the immense cost his Alpine project would entail if it were actually constructed, but writes, "...it is a confirmation of the value of the project when it in fact requires no less in the way of monies and masses of men than the World War is swallowing up." 2 The preface continues, "At any rate, in the war Europe has proven one thing: the degree of mental stamina and energy of which it is capable. And if these forces can successfully be channeled in a different, finer direction, then the Earth will in truth be a 'good dwelling'." In other words, Taut justifies his architectural fantasies by asserting that the war effort proves how capable Europeans are at achieving anything, even the improbable. $\mathrm{He}$ wants to use his design propositions as an alternative channel for the money and energy expended on war. In his mind, if Europeans are busy constructing a utopian paradise, they will be too busy to wage war. At the same time, he justifies his project for its "purifying" and "resolving" abilities. In Taut's mind, the productive activities involved in realizing Alpine Architecture will help heal some of the wounds caused by the war.

${ }^{1}$ MTA, AdK, 01-1155; trans. Matthias Schirren, 122.

${ }^{2}$ Bruno Taut, unpublished introduction to Alpine Architektur, ALP.01.42, AdK. 
Figure 5. The Crystal House, page 3 of Alpine Architecture ${ }^{1}$

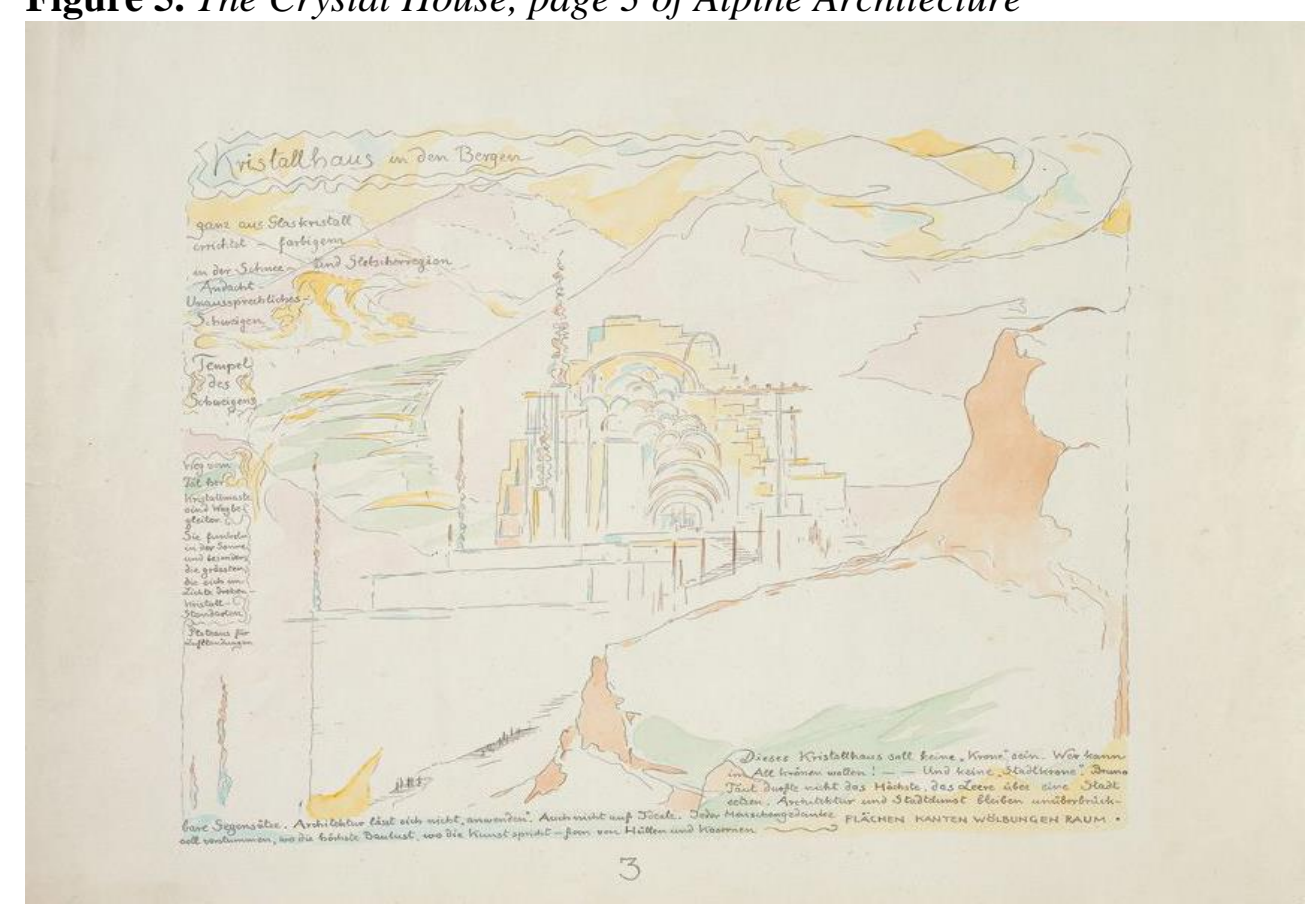

Photo: Akademie der Künste, Berlin

The motto of Alpine Architecture is: "Building is necessary, living is not necessary," a strange, even fanatical, statement about the importance of architecture to life. The book is divided into what Taut called the "symphonic form," five sections: Crystal House, Architecture of the Mountains, Alpine Building, Earth Bark Construction, and Star Building, so that the book moves from utopian, but, perhaps, realizable to the futuristic and fantastic. (Figure 5) The entrance to the Crystal Houses is through a steep path and over bridges all made of coloured glass therefore reminiscent of the Glass Pavilion design of 1914. But, the architecture has virtually no structure, as in the Temple of Silence - the visitor eventually reaches the glass city at the top. In the text, Taut denies that the design represents an "ideal" rather, he argues, "every human thought should cease where the highest building art, where the art speaks - far from huts and barracks." 2 Taut is presenting a new world as the alternative to the one that existed before and during the war.

Taut's analogy to the symphony is significant since it was the great pioneering German composer, Beethoven, who first expanded the symphonic form from four movements to five in his Pastoral Symphony. Not only did the symphony break with classical form but also it was composed around natural themes such as "feelings upon arrival in the country," "scene at the creek" and

\footnotetext{
${ }^{1}$ The caption reads: Crystal House in the Mountains: Realized totally out of glass crystal coloured in the snow - and thought of for the glacier region - ineffable silence - Temple of Silence. The way from her deed. Crystal examples are way companions. They sparkle in the sun and especially the large ones are turning to the light. Crystal standards. Plateaus for air landings.

${ }^{2}$ Bruno Taut, Alpine Architektur (Essen: Folkwang, 1919), 3.
} 
"joyful reunion of peasants." Taut likely wished to suggest that Alpine Architecture presented the joy of retiring to nature and that the work was as innovative as Beethoven's, nonetheless like the symphony still connected to tradition.

The book begins with a drawing entitled Ascent from the Mountain Lake. In it, Taut pictures a delicate structure rising out of the water. Behind the building, there is a steep incline with "pointed palisades" surrounding a treacherously pitched stair. The goal, the Crystal Building, is not visible. (Figure 6) The water acts analogically like the river Styx - as the division between two worlds. By passing over the water, the visitor leaves the ordinary world behind and enters a new world.

Figure 6. Crystal Mountain, page 7 of Alpine Architecture ${ }^{1}$

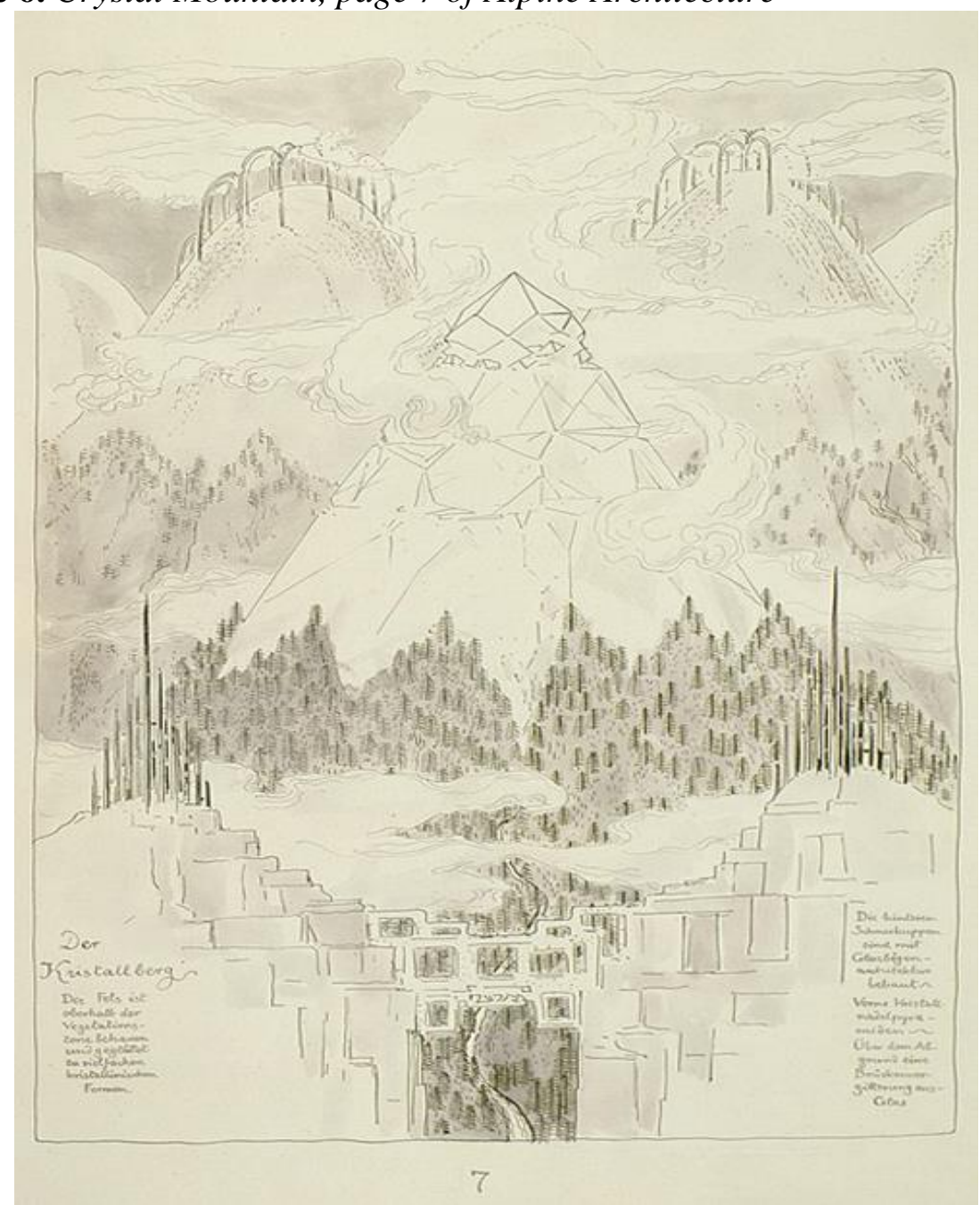

Photo: Akademie der Künste, Berlin.

\footnotetext{
${ }^{1}$ The caption reads: The Crystal Mountain: The rock is hewn and smoothed above the vegetation zone and made into multiple crystalline forms. The distant snow caps are built with glass arched architecture. In front, crystal needle pyramids - Over the chasm is a glittering bridge of glass.
} 
The new world Taut imagines is fanciful and magical. He renders the architecture in pastel hues, with an abundance of bright yellow that heighten the unreal, idyllic quality of the drawings. The illustrations resemble ones from a child's picture book. The colour choices, translucent application of tone and saturated hues, and whimsically cheerful quality supports the notion of Alpine architecture, being utopian rather than utilitarian or real. They also reinforce the project as the antithesis of the gloomy battlefield. Still Taut sees an inextricable connection between artistic and utilitarian aspects of design. When he writes, "Architecture and house are not separable concepts" Taut is alluding to the importance of, and indissoluble connection between, the artistic and utilitarian in good design. ${ }^{1}$ He concedes that realizing the project is: "Certainly tremendously difficult and full of victims, but not impossible." ${ }^{2} \mathrm{He}$ continues: "Impractical and unusable - but are we made happy from utility?"3 Taut's pronouncements underline the danger in an over concern with function and utility.

Taut continues, "Have useful things brought happiness? Incessant use and utility: comfort, ease - fine dining - knife, forks, railways, lavatories and not to forget oh - cannons, bombs, murder devices! Merely desiring utility and comfort without a higher idea is bore-dom causes quarrelling strife, and war: lies, rapine, murder, misery, bloodshed a million million times over." 4 Taut is subtle but makes sure his reader understands that one reason for constructing the Alpine project is that it is an anti-civilization proposition - it offers an antidote to the usual trappings of human life, the objects that might seem innocent enough, but ultimately are related to the inventions that result in war machines and death. Furthermore, he admonishes the reader about the dangers of boredom. "And if the slavery doesn't abate - no matter, as long as people have a single task and can no longer think of stupid wars and quarrelling. Boredom is the source of all evil." ${ }^{, 5}$ He believes that war occurs when people have nothing constructive to occupy their time. "Bring strife, conflict and war: lying, murder, misery, millions flowing blood. Sermon: ready peace! The boredom disappears and with it the strife, politics and the wicked ghost war...Of peace, no one needs to talk, if there is no more war. There is only still restless idle work in the service of beauty...." For Taut, then, the act of building will distract humankind and therefore bring peace. At the same time, constructing an ideal, beautiful architectural complex in a place of natural beauty would inspire peace.

The project of Alpine Architecture offers an alternative to war namely, the adornment of the Earth. Taut devotes a great deal of the drawings and some of the text to this idea: "Nations of Europe! Shape your sacred assets! Build! Give

\footnotetext{
${ }^{1}$ Alpine Architektur, 5.

${ }^{2}$ Alpine Architektur, 10.

${ }^{3}$ Alpine Architektur, 16.

${ }^{4}$ Ibid.

${ }^{5}$ Bruno Taut letter to his wife, Hedwig, dated 2 Nov. 1917, BTA, AdK 01-94; translated by Matthias Schirren, Bruno Taut: Alpine Architektur Eine Utopie (Muncih: Prestel 2004), 120.

${ }^{6}$ Alpine Architecture, 16.
} 
a thought to your planet, Earth which wishes to adorn itself - through you!"1 The types of adornment range from crystalline buildings as in the drawings Crystal House in the Mountains, in Crystal Houses, and Valley with Rich Architecture, to waterfalls, to abstract vertical elements scattered in the landscape in Great is Nature, and The Rocks Live, to crystals dotted in the landscape like some form of natural jewelry in Great is Nature. Again, the scenes Taut draws are unreal, artistic representations rather than utilitarian ones.

The extreme rejection of utility in Alpine Architecture is evident at several levels. As already mentioned, the ways Taut draws and renders his images makes them seem imaginary rather than depictions of real situations. Utopian images abound in the folio. They include the rainbow filling the sky in the foreground of the drawing of the Hill with Rich Architecture, a cascading glass building that has water flowing over it in a series of artificial waterfalls in Valley with Rich Architecture, the gleaming crystal structures of Snow with Ice and Ferns, and the crystalline cities in The Construction Area. Taut writes below the drawing: "Aeroplanes and airships bring happy people, who are grateful to [be freed] of illness and suffering...." He also ignores structural constraints and other real world challenges that architecture faces. Thus, much of the architecture lacks any structure whatsoever. The glass buildings on the Monte Rosa resemble blown glass ornaments rather than real buildings. "Technology is always only a handmaiden," Taut writes, "and now it shall no longer serve low instincts...but the striving of the truly active human spirit." Practical and realizable architecture responds to the baser human instincts and therefore has no place in Taut's Alpine imaginations.

The Appeal to the Europeans is situated at the physical centre of the book, an analogy for its importance as the explicit moral message contained in Alpine Architecture. As Matthias Schirren points out, the page is designed as a cross, to indicate the intersection between moral, ethical and spiritual import conveyed by the Appeal. ${ }^{4}$ At the same time, the Appeal marks a change in direction in the book. From this point, the drawings become less and less real and more and more embedded in the mystical and imaginary. The locations remove from the surface of the Earth to outer space; the structures shift from building like to astral systems. The Ralik and Ratak Islands image shows what appears to be an inverted mobile alighting on the sea. The Mountain Night is an abstract composition of overlapping triangulated fields of colour, with no perspectival space or recognizable elements. Its caption reads: "To know the Transcendent!" clearly signalling for the reader not only Taut's numinous intent but also connecting the work to Meister Eckhart's transcendentalism and to Oriental spirituality, two subjects Taut was fascinated with throughout his life. From the end of Part Three, the text and images leave planet Earth for ever more remote locations among the stars in outer space as if to underscore the

\footnotetext{
${ }^{1}$ Ibid.

${ }^{2}$ Ibid, 17 .

${ }^{3}$ Ibid, 16.

${ }^{4}$ Schirren, 91.
} 
fanciful aspect of the book. The Fifth Section is titled, Star Building. It features the Cathedral Star, Cave Star, a solar system like image, and the System from Systems Worlds and Fog, culminating with the "Star worlds sleep death the great nothingness the nameless end."1 (Figure 7) Taut's apocalyptic closing pronouncement is less a conclusion than an affirmation of his devotion to transcendental thinking.

Figure 7. The Ball; the Rings; the Wheels!

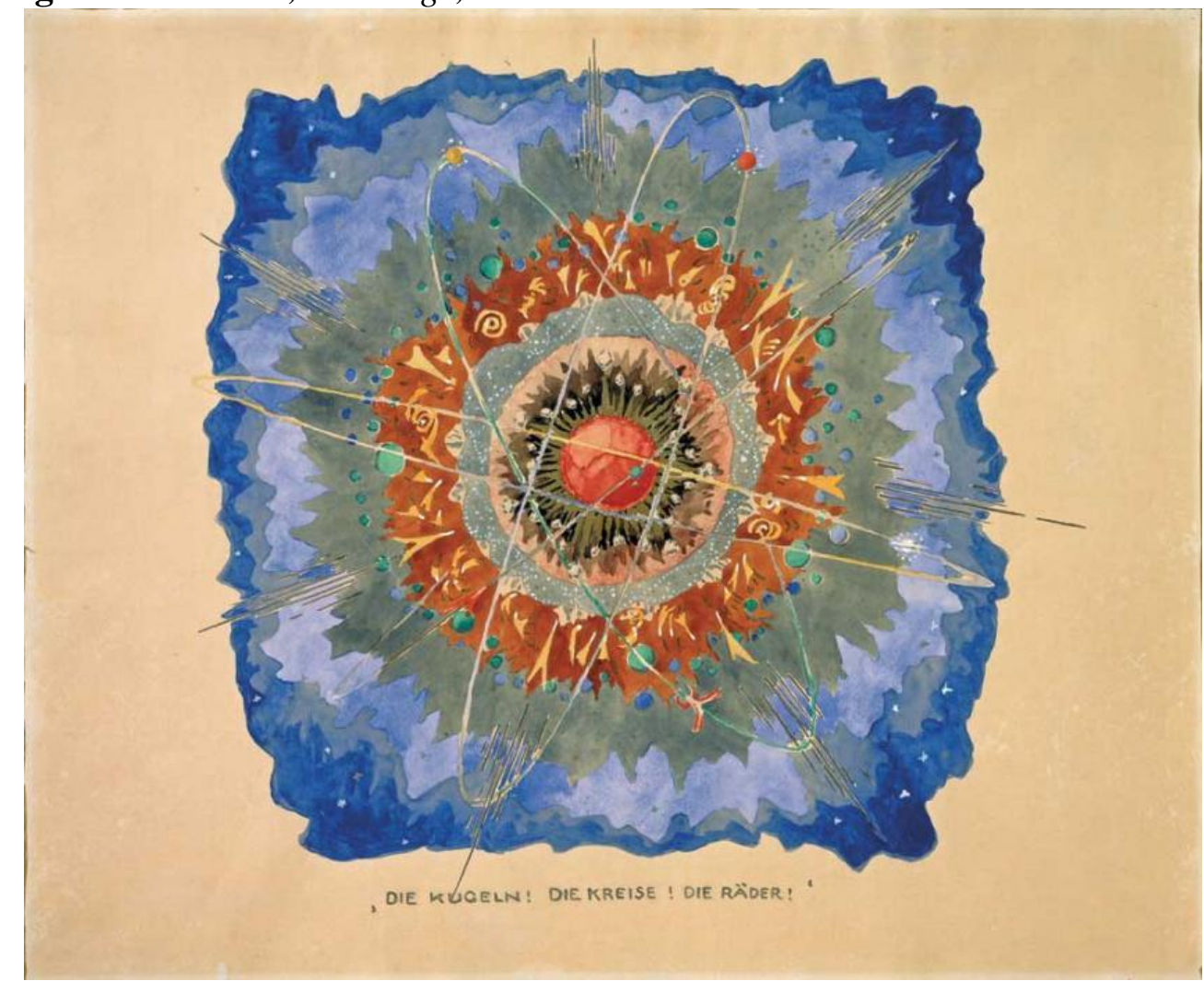

Photo: Akademie der Künste, Berlin

Schirren suggests that the formation of stars and planets in space might be an analogy for how the artist thinks and creates. Rather than an ordered and rational approach to making, the creative mind contains a sea of unformed ideas swirling around until those ideas coalesce. By making the more abstract section the apotheosis of the project, Taut suggests the primacy of artistic and creative thinking over rational thinking. It is with such thinking that man can overcome the constraints of earthly life and problems like war, and strife to achieve peaceful coexistence.

Taut responded to the war by devoting his considerable drawing abilities to a new purpose. Alpine Architecture was the first project in which Taut used drawings of fanciful architectural propositions as solutions to societal problems; the first time he harnessed his artistic drawing talents as a polemical propaganda tool. The war experience heightened Taut's interest in using

${ }^{1}$ Alpine Architektur, 30. 
architecture as an instrument for social good. At the same time, the war clearly provoked and inspired the change in Taut's focus from realistic engagement with specific social problems through buildable architectural solutions to utopian propositions designed to cure fundamental ills of the human condition. While the impulse driving Taut may have been similar before and after the war, afterwards, his ambitions were far greater and more radical in scope.

\section{References}

Behne, Adolf, "Das Monument des Eisens," Allgemeiner Beobachter 3, no. 12, October 1913, 167.

Behne, Adolf. "Das Monument des Eisens," Kunstgewerbeblatt, 25, no. 5, February 1914, 86-88.

Bruno Taut 1880-1938 Architekt zwischen Tradition u. Avantgarde. edited by Winfried Nerdinger, Kristiana Hartmann, Matthias Schirren, Manfred Speidel. Munich: Deutsche Verlags-Anstalt, 2001.

Frühlicht, ed. Bruno Taut. Spring 1921.

Gutschow, Kai. "From Object to Installation in Bruno Taut's Exhibit Pavilions," Journal of Architectural Education, vol. 59, Issue 4, May 2006, 63-71.

Lamberts, Brigitte Renate Vera. Das Fruhwerk von Bruno Taut (1900-1914), diss. University of Bonn, 1994.

Paul Scheerbarts Briefe von 1913-1914 an Gottfried Heinersdorff, Bruno Taut und Herwarth Walden ed. Leo Ikelaar. Paderborn: Igel, 1996.

Schirren, Matthias. Bruno Taut: Alpine Architektur Eine Utopie. Muncih: Prestel 2004.

Taut, Bruno. Alpine Architektur. Essen: Folkwang, 1919.

Taut, Bruno. "Baugedanken der Gegenwart," Die Bauwelt, 1923, 341.

Taut, Bruno. "Glasbau," n.d. Bruno Taut Archive, AdK, BTS 01-47.

Taut, Bruno. "Kleinhausbau und Landsaufschliessung vom Standpunkt des Architekten," Gartenstadt: Mitteilungen der Deutschen Gartenstadtgesellschaft, $8 \mathrm{Jg}$, Heft 1, 1914, 9-12.

Taut, Bruno. "Kriegs-Ehrung," Kunstgewerbeblatt, 1915, 174.

Taut, Bruno. "Eine Notwendigkeit," Der Sturm, No. 196, 1913, 174-175.

Taut, Bruno. Die Neue Wohnung. Leipzig: Klinkhardt \& Biermann, 1924.

Taut, Bruno. "Natur und Baukunst," Stuttgart, 1904.

Volkmann, Barbara. Bruno Taut 1880-1938. Ausstellung der Akademie der Künste vom 29. Jun ibis 3. August 1980. Berlin: AdK, 1980.

Whyte, Iain Boyd. Bruno Taut and the Architecture of Activism. Cambridge: CUP, 1982. 
